\title{
Repair of Fire-Damaged Reinforced Concrete Members with Axial Load: A Review
}

\author{
Jun Zhou and Lu Wang * \\ College of Civil Engineering, Nanjing Tech University, 30 Puzhu South Road, Nanjing 211816, China; \\ timberzhoujun@hotmail.com \\ * Correspondence: kevinlwang@njtech.edu.cn
}

Received: 23 December 2018; Accepted: 12 February 2019; Published: 13 February 2019

\begin{abstract}
It is common knowledge that structural fires have led to a great loss of buildings and damage to property in the past two decades. Therefore, there is a growing need to provide approaches for post-fire repair of structural members to enhance their structural safety. This paper presents a state-of-the-art review on the repair of fire-damaged reinforced concrete (RC) members with axial load. The investigations into the effects of loading method, physical dimension and bonding behavior on the residual strength of members are presented. In the meantime, the available experimental investigations on the performance of fire-damaged RC members with axial load repaired with concrete jacketing, steel jacketing and fiber-reinforced polymer (FRP) jacketing are summarized. Moreover, models for predicting the residual strength of fire- damaged columns are reviewed.
\end{abstract}

Keywords: fire exposed; reinforced concrete columns; residual strength; repair of concrete structures; repair method

\section{Introduction}

The ultimate strength of RC columns degrades in fire due to the decrease in both the strength and stiffness of the material. Hence, there is a growing need to provide measures for post-fire repair of columns to enhance the structural safety. The external jacketing is often adopted to repair fire-damaged $\mathrm{RC}$ columns since it is recognized as one of the most cost-effective and convenient approaches to strengthen damaged RC columns. Up to now, three main repairing techniques are available for column repairing: concrete jacketing, steel jacketing and FRP jacketing. All the jackets are placed around the damaged columns to increase the sectional area and provide the confinement of the concrete so as to directly or indirectly recover the designed ultimate strength of the damaged columns.

Concrete jacketing is a typical concrete-strengthening method through increasing the sectional area to improve the ultimate strength of fire-damaged RC columns. The slenderness and axial compression ratio of the RC column can be decreased, and the stiffness of RC column can be grown because of the larger sectional area and more reinforcement. Hence, a lot of RC columns have been strengthened with concrete jacketing. However, many problems exist in the procedure of construction, such as the long construction period and huge construction quantities. Meanwhile, the dead weight of structure has also been increased. The appearance of building and interior space will be affected too. Furthermore, for the concrete jacketing, it cannot actively share the existing compression loading in the original RC column until it is subject to the additional loads. Therefore, the stress lagging effect exists between the two parts, and the concrete jacketing cannot reach the limitation state while the original RC column has been failure.

Steel jacketing can be tracked from the 1980s. The "tubed column", as the rudiment of steel jacketing, was proposed in 1986 [1]. Nowadays, the Steel jacketing technique has been applied in the practice of construction worldwide, especially in the USA, Czech Republic and Japan. At the 
preliminary stage, the steel jacketing is mainly applied to seismic retrofitting and for improving the shear strength of the RC columns. The jacketing was effective in passive confinement, which can be considered equivalent to continuous hoop reinforcement. However, for the rectangular RC columns, the steel jacketing would be buckling at the plastic hinge area of the column when it is subjected to the lateral displacement, which was confirmed by the experiment [2,3]. To avoid the buckling of steel jacketing at the plastic hinge area, stiffener was applied by Xiao et al [4]. The steel jacketing using angles and stirrups originates with Cirtek from Czech Republic [5,6]. Up to now, over 5000 RC columns have been strengthened successfully with this method in the Euro. Comparing the elliptical tube, the main advantage of this method is repairing columns without cross-section enlargement [7-19].

FRP is a composite material made of extremely fine fibers embedded in a matrix, which is commonly made with three types of fiber, namely carbon, aramid and glass. Hence, according to the different fibers, the FRP can be represented with three symbols, CFRP, AFRP and GFRP, respectively. The FRP material has the following features: high strength/stiffness-to-weight ratio and anti-corrosion ability [20-22]. Furthermore, the stress-strain relationship of FRP is linearly elastic before rupture [23]. Hence, when the concrete was confined by FRP, the strength and ductility of RC columns were improved. Due to these above advantages, the use of bonding FRP has become popular in recent years, involving the repairing of fire-damaged RC columns [24-31].

A lot of experimental and analytical investigations on the repairing of fire-damaged columns are available [32-35]. This paper aims to present a literature review of repair methods for fire-damaged RC columns. Summarized reviews of recent information about the performance of RC columns subjected to fire including influences of loading method, physical dimension and bond behavior, repairing methods, and analytical modelling are also included in this article.

\section{Behavior of Reinforced Concrete Compression Members at Elevated Temperature}

\subsection{Effects of Additional Eccentricity}

In the construction, columns may suffer from a one-, two-, three-, or four-face fire damage. For columns under one- and three-face heating, the uniaxial bending should be considered, while for two- or four-face fire exposure, the effect of biaxial bending should be considered. Tan et al. [36,37] proposed an accurate and consistent method to evaluate the fire resistance of RC columns subjected to four-face heating, although the effect of concrete spalling was not considered. The same method applies to one-, two- or three-face fire heating. Jau et al. [38] studied the performance of corner columns which suffered from two-face heating under axial loading, biaxial bending, and asymmetric fire loading. It was found that the residual strength decreased with increasing fire exposure time.

\subsection{Physical Dimension}

Lie et al. [39-41] established an analytical model to calculate the fire resistance of RC columns. The value of parameters like section dimensions and load can be obtained by using this model. Wu et al. [42] conducted the tests of the square RC columns to study the effect of dimensions. Increasing the dimension of columns cross section was an effective measure for improving the fire resistance of RC columns.

\subsection{Bonding Behaviour}

Bonding behavior between reinforcement and concrete has been widely studied over the past two decades. It was investigated at elevated temperature by employing standard pull-out specimens [43-45]. According to the rate and type of heating, Bosnjak et al. [46] developed a thermal model to conclude that concrete degradation and cracking may cause the change in the failure modes from pure bond failure to the splitting failure. In general, residual bonding strength decreased with an increase in temperature. Figure 1 shows the residual bonding strength with temperature. 


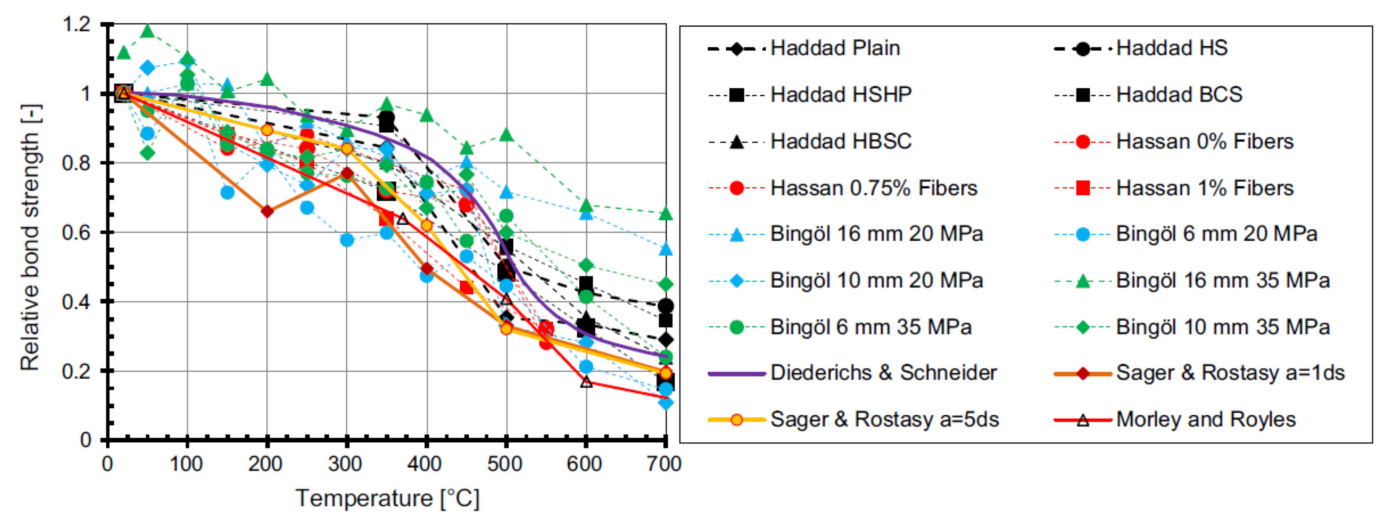

Figure 1. Bond strength degradation at an elevated temperature according to pull-out tests. (adapted from Reference [46]).

\section{Repair Methods for Compressed Structural Elements}

\subsection{Section Enlargement Strengthening}

Section enlargement strengthening is a reinforcement method for increasing the sectional area to achieve the purpose of improving the ultimate axial load-bearing capacity, stiffness and stability. Since the construction process of section enlargement strengthening is simple, it has become the most common repair method for current applications.

In the past 20 years, Bett et al. [47] studied three different repair techniques on stocky RC columns which were enhancing the lateral load response. Two columns were strengthened before testing, while one column was repaired after testing. All of them were under axial compression and reversed cyclic lateral loads. The dimensions of the specimens are shown in Table 1. However, it is mainly applied to the reinforcement of the bridge after a fire, while it is hardly applied in the RC frame structures due to the reduction of the space area. Deng and Wang [48] evaluated the performance of the bridge columns after 2-hour fire exposure. The residual strengths of the fire-damaged columns were calculated. Finally, the section enlargement method was adopted to repair the fire damage bridge columns. The resilience method and bore core method were used to test the strength of concrete and charring depth, respectively. The enlarged section is shown in Figure 2. Moreover, the damaged part is concentrated on the beam end, where the shearing force was large so that only the shear reinforcement design was needed. Figure 3 shows the comparison of the shear bearing capacity of the beam before and after reinforcement. This research can provide a reference for on-site inspection, damage identification, and bearing capacity evaluation of the bridge columns after the fire. An experimental program was carried out by Liu et al. [49] to study the behavior of fire-damaged RC columns repaired by the section enlargement method. The specimens were subjected to three-side fire exposure. The test results showed that the ultimate strength of the repaired specimens were improved. Table 1 summarizes some of the experimental fire tests conducted on columns. Gholampour et al. [50] used high-strength polyethylene fiber-reinforced concrete for jacketing to strengthen the damaged RC columns. Compared with three different horizontal reinforcement ratios of the fiber-reinforced concrete jackets, the tests results demonstrated that based on the interaction between the conventional reinforcement and fibers, ductility only existed in samples containing stirrups and fibers. Furthermore, under a given axial strain, the more fiber content, the greater the lateral strain of the jacket layer. 


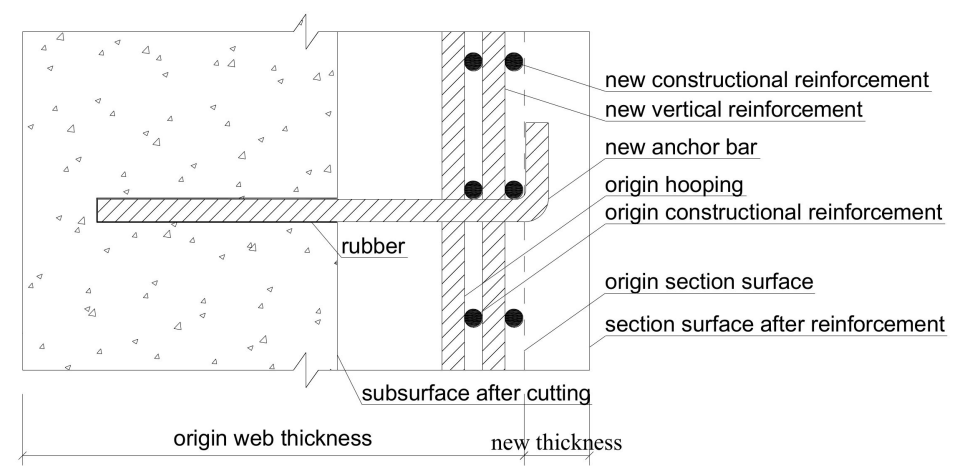

Figure 2. Layout of reinforcement (adapted from Reference [48]).

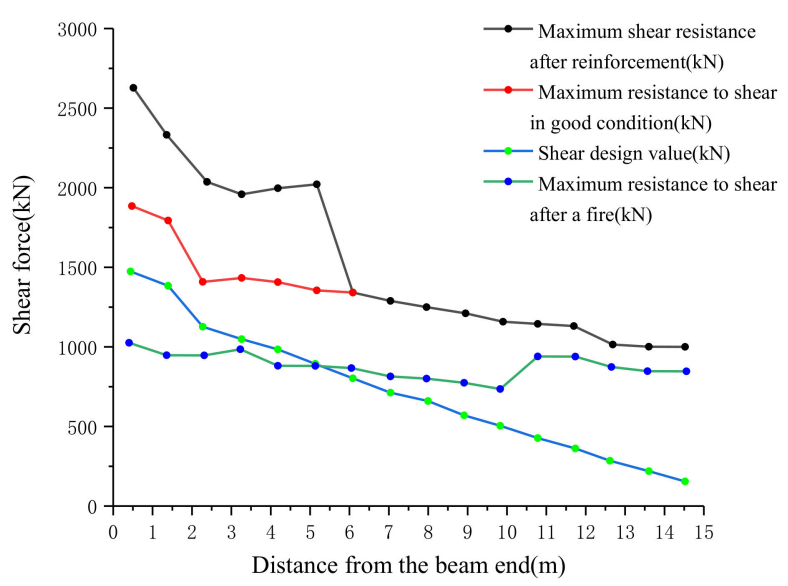

Figure 3. The comparison of the shear bearing capacity of the beam before and after reinforcement (adapted from Reference [48]).

\subsection{Steel Wrapping Method}

The steel wrapping method means that the steel parts, such as steel plates, channels and tubes, were bonded at the corners and surfaces of columns with cement mortar or epoxy resin, as shown in Figures 4 and 5 .

Fu et al. [51] established a repair scheme to recover the ultimate strength of the fire-damaged columns. The fire damage is divided into four grades, as listed in Table 2. It is suggested that the second stage damaged column can be repaired by the section enlargement method, and the third stage damaged is suitable for the steel wrapping repair. The steel angles were installed at the four corners of a column, which were connected as a whole by the splicing plate. The thickness of steel angle was determined by the designed bearing capacity. The lower end of the steel angle was anchored into the foundation, and the upper end extended to the bottom of the upper floor.

Wang and Su [52-58] developed the post-compressed steel plates method to repair the firedamaged columns. Seven RC columns were subjected to 4-hour fire exposure. For each column, two slightly precambered plates were bolted to an RC column. The plates were longer than the clear height of the column. When the anchor bolts were progressively tightened, a thrust was generated on the end supports due to arching actions, which resulted in a post-compressive force developed in the steel plates and an equal magnitude de-compressive force induced in the RC column. Hence, the existing applied loads could be resisted by both the RC column and steel plates. The test results showed that the ultimate strength of fire-damaged columns retrofitted with post-compressed plates can restore up to $72 \%$ of the original strength level. 


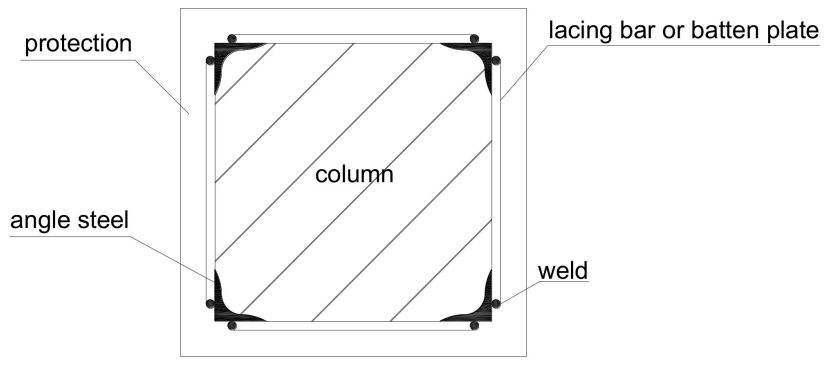

Figure 4. Steel wrapping strengthening.

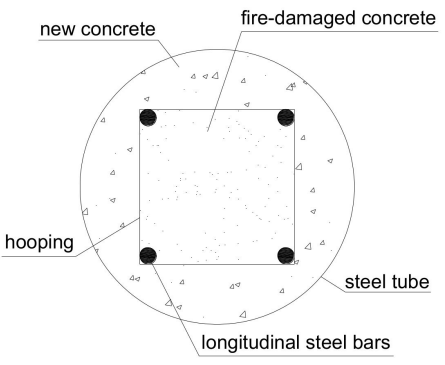

(a) Circle

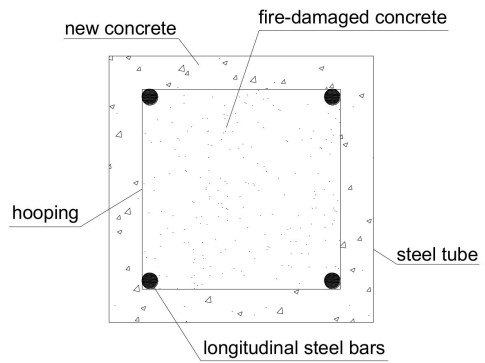

(b) Square

Figure 5. Steel tube wrapping.

Table 1. Details of some experimental fire tests conducted on columns.

\begin{tabular}{|c|c|c|c|c|c|}
\hline Reference & $\begin{array}{l}\text { Reinforced } \\
\text { State }\end{array}$ & $\begin{array}{l}\text { Column } \\
\text { Size }(\mathrm{mm})\end{array}$ & Load Type & $\begin{array}{l}\text { Temperature } \\
\text { Range }\left({ }^{\circ} \mathrm{C}\right)\end{array}$ & Destructive Feature \\
\hline $\begin{array}{l}\text { Liu et al. } \\
\text { [49] }\end{array}$ & $\begin{array}{l}\text { Before } \\
\text { After }\end{array}$ & $\begin{array}{l}100 \times 200 \\
100 \times 300\end{array}$ & Eccentric & 20 to 800 & $\begin{array}{c}e_{0}<40 m m, \text { full section compression } \\
\text { damage; }\end{array}$ \\
\hline $\begin{array}{l}\text { Bett et al } \\
\quad[47]\end{array}$ & $\begin{array}{l}\text { Before } \\
\text { Before } \\
\text { After }\end{array}$ & $\begin{array}{l}305 \times 305 \\
432 \times 432 \\
432 \times 432\end{array}$ & $\begin{array}{l}\text { axial } \\
\text { compression } \\
\text { and cyclic }\end{array}$ & Normal & $\begin{array}{l}e_{0}<40 \mathrm{~mm} \text {, partly tensile damage } \\
\text { The brittle and shear-dominated failure }\end{array}$ \\
\hline Sun [59] & Before & $100 \times 200$ & $\begin{array}{l}\text { lateral loads } \\
\text { Eccentric }\end{array}$ & 20 to 800 & $\begin{array}{c}e_{0}>0 \text {, concrete cracking in the tension } \\
\text { zone; } \\
e_{0}<0 \text {, compression damage }\end{array}$ \\
\hline
\end{tabular}

Table 2. Damage classification.

\begin{tabular}{ccccc}
\hline Damage Level & Level One & Level Two & Level Three & Level Four \\
\hline Degree of damage & Mild & Moderate & Serious & Dangerous \\
$\begin{array}{c}\text { Concrete temperature }\left({ }^{\circ} \mathrm{C}\right) \\
\text { longitudinal reinforcement }\end{array}$ & $<400$ & 400 to 500 & 600 to 700 & $\geq 700$ \\
Temperature $\left({ }^{\circ} \mathrm{C}\right)$ & $<100$ & $<300$ & 350 to 400 & 400 to 500 \\
Damaged situation & $\begin{array}{c}\text { No significant } \\
\text { changes }\end{array}$ & $\begin{array}{c}\text { Deflection } \\
\text { meeting the limit }\end{array}$ & $\begin{array}{c}\text { Deflection exceeding } \\
\text { the limit by 1 to 3 times }\end{array}$ & $\begin{array}{c}\text { Out-of-plane } \\
\text { deformation }\end{array}$ \\
\hline
\end{tabular}

\subsection{Externally Bonded Reinforcement Strengthening (EBR)}

Fiber-reinforced polymer (FRP) has been increasingly used in civil engineering applications due to its advantages of its excellent strength to weight ratio and anti-corrosion ability [60-66]. As a mature technology, FRP sheets were bonding onto the surface of RC columns to restore the ultimate load capacity due to the confinement effect [67-75]. Figure 6 shows the EBR procedure for RC column elements [76]. The strength-temperature curve for concrete, steel and FRP can be seen in Figure 7.

Tao et al. [77] performed an experiment to investigate the compressive performance of firedamaged concrete-filled steel tubular columns repaired by FRP jacketing. Compared with the loadbearing capacity of circular or square columns, it can be concluded that the FRP jacketing can enhance the load-bearing capacity and stiffness effectively. The specific parameters of the square and circular 
members are shown in Table 3. The study on fire behavior of concrete-filled steel tubular columns repaired by FRP jacketing was conducted by Tao et al. [78]. They analyzed the failure modes of columns after fire, temperatures distribution, and axial deformation of fire-damaged columns. Moreover, the fire resistance of the repaired columns was also studied. The test results showed that the FRP jackets can be rubbery and viscous reaching the glass transition temperature (Tg). Hence, it can be assumed that the strength of the externally bonded FRP system was lost completely in a fire if the insulation thickness was less than $10 \mathrm{~mm}$. Figure 8 shows that the required insulation thickness will reduce to $11.7 \mathrm{~mm}$ if $\mathrm{Tg}$ increases to $300{ }^{\circ} \mathrm{C}$. Janwaen et al. [79] proposed a new repair method for increasing the ultimate load capacity of rectangular RC columns under axial loads. The CFRP sheets with a certain prestress level were adopted to confine the concrete. Compared with the traditional method, the test results showed that the increase of ultimate strength per quantity of CFRP sheets of repaired columns was higher. Haji et al. [80] developed an innovative hybrid-strengthening method using FRP sheets. Six specimens had been tested under constant axial load and lateral cyclic load. Compared with the Near Surface Mounted technology, the ultimate strength, ductility, and stiffness of columns strengthened with the hybrid method increased significantly. Yaqub and Bailey [81] conducted an experimental study to investigate the axial capacity of circular RC columns after fire exposure strengthened by FRP. The test results showed that the axial strength and ductility of repaired columns increased significantly, but the stiffness improved slightly. Roudsari et al. [82] used ABAQUS coupled with Matlab to analyze the RC columns under the axial load strengthened by FRP. The actual behavior of materials and damage-plasticity of concrete were considered. Compared with the test results of 22 concrete axially loaded columns, it can be concluded that it did not matter if it was GFRP or CFRP, the ultimate load capacity of columns greatly improved.

Table 3. Specimen details and capacities for stub columns.

\begin{tabular}{|c|c|c|c|c|c|c|c|c|c|c|}
\hline $\begin{array}{l}\text { Section } \\
\text { Type }\end{array}$ & $\begin{array}{c}\mathrm{D}(\mathrm{B}) \times t_{s} \\
(\mathrm{~mm} \times \mathbf{m m})\end{array}$ & $\begin{array}{c}\mathrm{L} \\
(\mathrm{min})\end{array}$ & $\begin{array}{l}\text { Layer(s) } \\
\text { of CFRP }\end{array}$ & $\begin{array}{c}f_{y} \\
\left(\mathrm{~N} / \mathrm{mm}^{2}\right)\end{array}$ & $\begin{array}{c}f_{c u} \\
\left(\mathrm{~N} / \mathrm{mm}^{2}\right)\end{array}$ & $\begin{array}{c}\text { Fire Duration } \\
\text { Time (min) }\end{array}$ & $\begin{array}{l}N_{u e} \\
(\mathbf{k N})\end{array}$ & $\begin{array}{c}E_{s c e} \\
\left(\mathrm{~N} / \mathrm{mm}^{2}\right)\end{array}$ & $\begin{array}{c}\text { SEI } \\
\%\end{array}$ & DI \\
\hline \multirow[t]{4}{*}{ circular } & $150 \times 3.0$ & 450 & 0 & 356 & 75 & 0 & 1915 & 46,285 & - & 5.51 \\
\hline & $150 \times 3.0$ & 450 & 0 & 356 & 75 & 180 & 913 & 15,592 & - & 3.95 \\
\hline & $150 \times 3.0$ & 450 & 1 & 356 & 75 & 180 & 1020 & 16,584 & 11.7 & 1.71 \\
\hline & $150 \times 3.0$ & 450 & 2 & 356 & 75 & 180 & 1560 & 19,695 & 70.9 & 1.22 \\
\hline \multirow{4}{*}{ square } & $140 \times 3.8$ & 420 & 0 & 318.5 & 75 & 0 & 1890 & 54,069 & - & 2.88 \\
\hline & $140 \times 3.8$ & 420 & 0 & 318.5 & 75 & 180 & 787 & 19,615 & - & 9.88 \\
\hline & $140 \times 3.8$ & 420 & 1 & 318.5 & 75 & 180 & 890 & 22,230 & 13.1 & 6.51 \\
\hline & $140 \times 3.8$ & 420 & 2 & 318.5 & 75 & 180 & 1000 & 25,009 & 27.1 & 2.59 \\
\hline
\end{tabular}

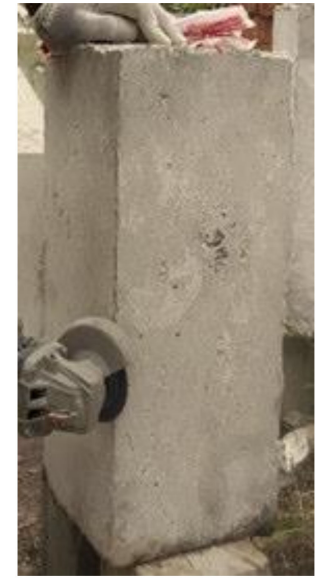

(i) Grinding of corners

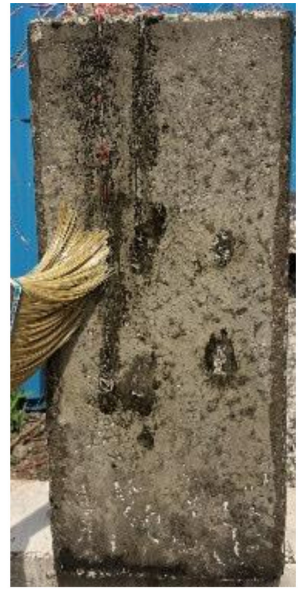

(ii) Application of primer

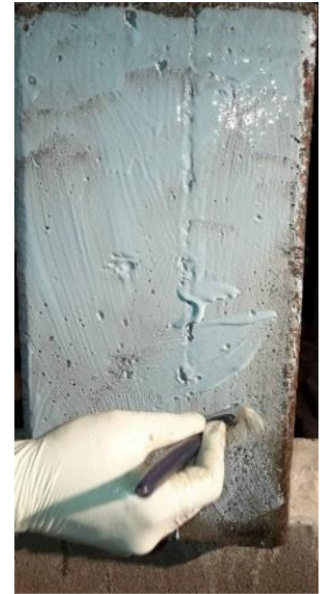

(iii) Expoxy coating

Figure 6. Cont. 


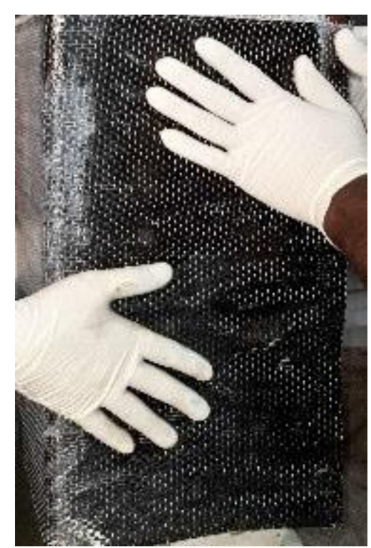

(iv) Wrapping of FRP fabric

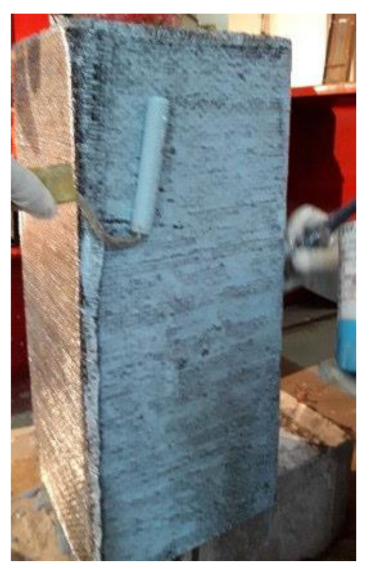

(v) Rolling to remove air bubbles

Figure 6. Procedure for EBR of RC Column elements (adapted from Reference [80]).

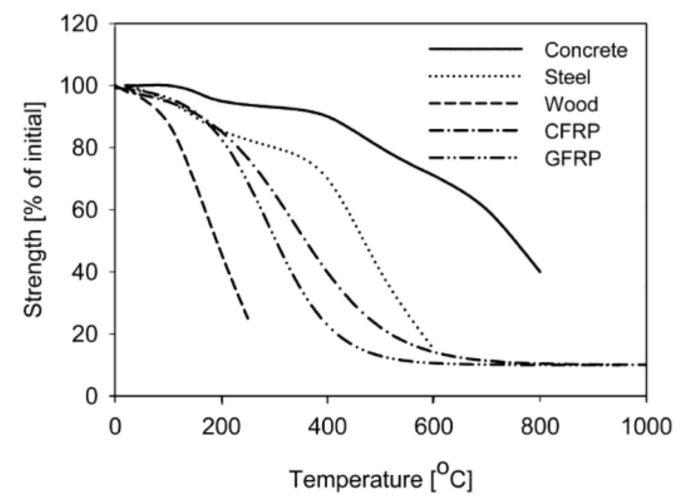

Figure 7. Strength-temperature curve for concrete, steel, and FRP.

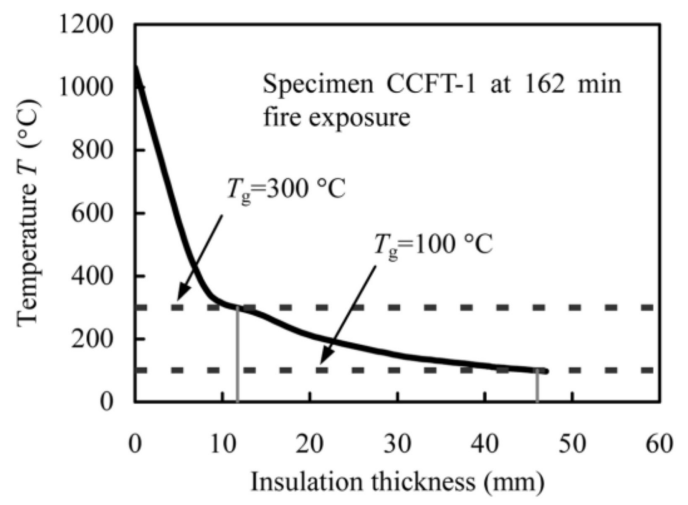

Figure 8. Effect of insulation thickness on the surface temperature of FRP wrapping. (adapted from Reference [78]).

In addition, fire resistance tests on FRP repaired RC columns were also investigated [83-94]. Bisby et al. [83] performed fire endurance tests on circular RC columns strengthened by FRP jacketing insulated with different thicknesses of fire protection. The test results demonstrated that with a certain fire insulation thickness, the temperature of the FRP wrapping can be kept below 100 ${ }^{\circ} \mathrm{C}$ for up to 4 hours during the standard fire exposure. A similar experiment was presented by Chowdhury et al. [84]. The results showed that concrete wrapping FRP with adequate fire protection can achieve a satisfying fire resistance rating; even FRP was sensitive to the elevated temperature. In particular, RC columns strengthened by FRP jacketing with appropriate fire insulation can endure 
high temperature for more than 5 hours. Similar test results were reported by Kodur et al. [85]. Table 4 summarizes the existing fire resistance tests on RC columns strengthened by FRP jacketing.

Table 4. The existing fire resistance tests on FRP-wrapped RC columns.

\begin{tabular}{ccccccc}
\hline Reference & $\begin{array}{c}\text { Column Size } \\
(\mathbf{m m}) \mathbf{h} \times \mathbf{B}\end{array}$ & Technique & $\begin{array}{c}\text { FRP } \\
\text { Material }\end{array}$ & $\begin{array}{c}\text { Thermal Insulation } \\
\text { and Thickness } \mathbf{( m m})\end{array}$ & $\begin{array}{c}\text { Strength } \\
\text { Increase (\%) }\end{array}$ & $\begin{array}{c}\text { Ultimate } \\
\text { Capacity (\%) }\end{array}$ \\
\hline $\begin{array}{c}\text { Bisby et al. } \\
\text { [83] }\end{array}$ & $400 \times 400$ & EBR & CFRP & $\begin{array}{c}\text { Vermiculite/gypsum } \\
\text { mortar, intumescent } \\
\text { coating }(32-57)\end{array}$ & 26 & 73 \\
$\begin{array}{c}\text { Chowdhury } \\
\text { et al. [84] }\end{array}$ & $400 \times 400$ & EBR & CFRP & $\begin{array}{c}\text { Cemt-based mortar } \\
(53)\end{array}$ \\
$\begin{array}{c}\text { Kodur et al. } \\
\text { [85] }\end{array}$ & $406 \times 406$ & EBR & GFRP & $\begin{array}{c}\text { Vermiculite/gypsum } \\
\text { mortar (38) }\end{array}$ & 10 & 56 \\
\hline
\end{tabular}

\section{Analytical Modelling of Compressed Members}

Although numerous analytical investigations have been conducted to simulate the behavior of reinforced concrete compressed elements at elevated temperature, very little literature has been conducted in repaired structural members after fire exposure. The relevant analytical studies are summarized in the following sections.

\subsection{Residual Bearing Capacity of Compression Elements}

Wang et al. [87] studied the residual strength of RC compression members after the fire and strengthened it with the enlarged section method. The load-bearing type of a compression member can be divided into axial compression and eccentric compression. The effective section of the fire column is a biaxially symmetric n-step ladder, rather than a rectangle at ambient temperature. The bearing capacity of four sides of a rectangular axial compression column subjected to fire may be defined as:

$$
N_{u T}=0.9 \varphi_{T}\left(A_{s T}^{\prime} f^{\prime}{ }_{y}+A_{c T} f_{c}\right)
$$

where $\varphi_{T}$ is the longitudinal bending coefficient and is equal to $1 / K(0.5 h) b . A_{c T}$ is the effective section on the compression side and is equal to $b \sum_{\mathrm{h}} K_{i} \Delta h . A_{s T}^{\prime}$ is the longitudinal steel reduction section. $f^{\prime} y$ is the tensile reinforcement strength. $f_{c}$ is the concrete compressive strength. These parameters are according to Chinese standard GB50010-2002. The same is true for large eccentric compression columns. However, for a small eccentric compression column, since tensioned steel bars may become compressed as the eccentricity changes, the pressure is divided into a step shape with an effective area $\Delta h b K_{A}(n)$ and a rectangle with an area $b K(n) \mathrm{X}_{1}$. If the neutral axis is in the middle rectangular section, the formula is as follows:

$$
\left.N_{u T}=\sum_{x} \Delta h_{i} K_{i} b a_{1} f_{c}+A_{s T}^{\prime} f_{y}^{\prime}-A_{s T} \sigma_{s}\right)
$$

Otherwise,

$$
N_{u T}=\Delta h b K_{A}(n) b a_{1} f_{c}+a_{1} f_{c} b K(n) X_{1}+A_{s T}^{\prime} f_{y}^{\prime}-A_{s T} \sigma_{s}
$$

where $\mathrm{K}$ is the reduction coefficient. $\mathrm{a}_{1}$ is the coefficient. $\sigma_{\mathrm{s}}$ is the strain.

Other researchers $[49,51]$ also used this numerical theory to verify their experiments. Furthermore, theory and experiment can better correspond. The results can be concluded that the section enlargement method can be selected when the compressed structural members have insufficient bearing capacity, stability or rigidity. Moreover, the load-bearing capacity, stiffness, and stability of the eccentric compression member reinforced by this method can be improved.

\subsection{Steel Wrapping Strengthening}

Wang et al. [88] conducted the numerical simulation of the mechanical performance of steel tube-wrapped RC columns after fire exposure. The influences of yielding strength, nominal steel rate 
and reparative concrete strength on bearing capacity, rigidity and ductility of the steel tube wrapped fire-damaged RC columns had been explored. For concrete-filled steel circle or square section columns, the yield strength of the steel pipe, nominal steel ratio, and concrete strength are compared respectively. These comparisons are shown in Figure 9. The test results showed that the ultimate strength and stiffness of the RC column after fire decrease obviously, while the wrapped steel tube can repair and strengthen the damaged RC column, and the strengthened composite column has greatly-improved bearing behavior.

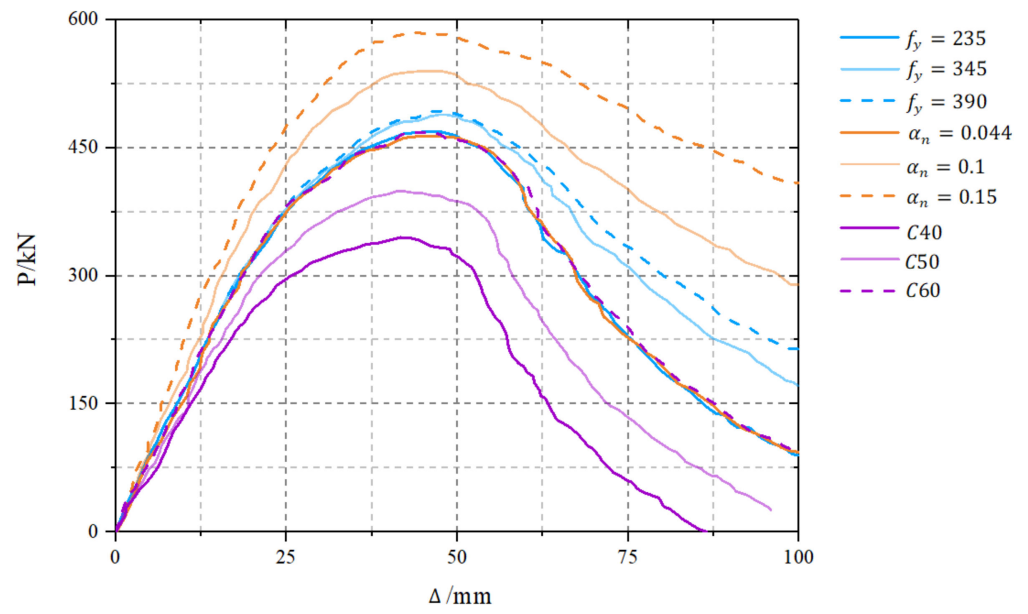

(a) Concrete-filled steel square section columns

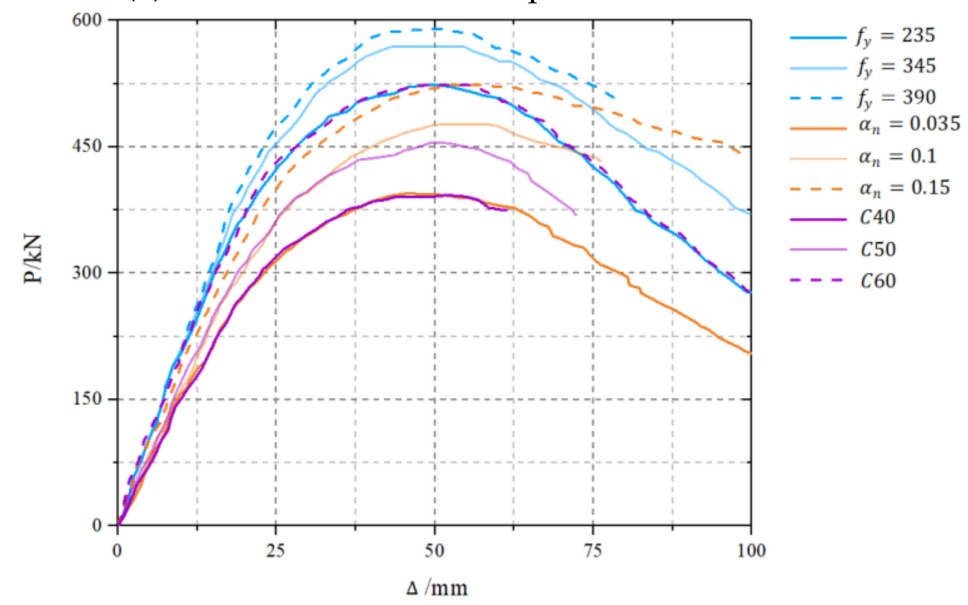

(b) Concrete-filled steel circle section columns

Figure 9. Comparison of concrete-filled steel tubular columns.

Compared with their experimental results, the fire resistance time model for the hybrid columns was developed by Han et al. [89]. The residual strength index (RSI) for the plain concrete-filled steel square hollow section (SHS) and rectangular hollow section (RHS) columns can be defined as:

$$
R S I= \begin{cases}\frac{1}{1+a t_{0}^{2}} & t_{0} \leq t_{1} \\ \frac{1}{b t_{0}^{2}+c} & t_{1} \leq t_{0} \leq t_{2} \\ k t_{0}+d & t_{0} \geq t_{2}\end{cases}
$$

where

$a=\left(\lambda_{0}^{3}-5.6 \lambda_{0}^{2}+6.6 \lambda_{0}+18.6\right) \cdot\left(-0.128 C_{0}+0.804\right) ;$

$b=\left(\lambda_{0}^{3}-7.79 \lambda_{0}^{2}+5 \lambda_{0}-4.53\right) \cdot\left(C_{0}^{2}-0.79 C_{0}-47.63\right) \cdot 3.61 \times 10^{-2}$; 
$c=1+(a-b) \cdot t_{1}^{2}$

$d=\frac{1}{b t_{0}^{2}+c}-k \cdot t_{2}$;

$k=\left(\lambda_{0}^{2}-5.98 \lambda_{0}+2.22\right) \cdot 3.36 \times 10^{-2}$;

$t_{1}=\left(\lambda_{0}^{3}-6.5 \lambda_{0}^{2}+2.5 \lambda_{0}+47.5\right) \cdot 7.6 \times 10^{-3} ;$

$t_{2}=\left(C_{0}^{2}-4.33 C_{0}+23.67\right) \cdot\left(\lambda_{0}^{2}-9.67 \lambda_{0}+40.33\right) \cdot 9.0 \times 10^{-4}$;

$t_{0}=\frac{R}{100} ; \mathrm{C}_{0}=\frac{\mathrm{C}}{100} ; \mathrm{C}=2(\mathrm{D}+\mathrm{B}) ; \lambda_{0}=\frac{\lambda}{40}$

\subsection{Fiber Reinforced Polymer (FRP) Strengthening}

At early stages, Bisby et al. [90,91] and Kodur et al. [92] evaluated the performance of FRP confined concrete subjected to fire exposure by numerical models. Moreover, the experimental tests [84-86] were conducted to verify the accuracy of the numerical simulation. The numerical model for predicting the fire resistance of circular FRP-confined columns was proposed by Bisby et al [91]. The unit-length column segment is shown in Figure 10. The temperature distribution of the FRP wrap can be written as follows.

$$
\begin{aligned}
& T_{m}^{i}=T_{m}^{i-1}+\frac{\Delta t}{2 \rho_{w} C_{w}\left[\mathrm{R}_{w}-(\mathrm{m}-1) \Delta \mathrm{x}_{w}\right] \Delta \mathrm{x}_{w}^{2}} \\
& \cdot\left[\left(\mathrm{R}_{w}-\left(\mathrm{m}-\frac{3}{2}\right) \Delta \mathrm{x}_{w}\right) \times\left(\mathrm{k}_{m-1}^{i-1}+\mathrm{k}_{m}^{i-1}\right)\left(T_{m-1}^{i-1}-T_{m}^{i-1}\right)\right. \\
& -\left(\mathrm{R}_{w}-\left(\mathrm{m}-\frac{1}{2}\right) \Delta \mathrm{x}_{w}\right) \times\left(\mathrm{k}_{m}^{i-1}+\mathrm{k}_{m+1}^{i-1}\right)\left(T_{m}^{i-1}-T_{m+1}^{i-1}\right)
\end{aligned}
$$

where $T_{m}^{i}$ is the temperature of element $m$ at $i$ step;

$T_{m}^{i-1}$ is the element temperature at $i-1$ step;

$T_{m+1}^{i-1}$ is the temperature of the adjacent element at $i-1$ step;

$\Delta t$ is the time internal;

$\rho_{w} C_{w}$ is the heat capacity of the FRP;

$k_{m}^{i-1}$ is the thermal conductivities of the current elements at $i-1$ step;

$k_{m+1}^{i-1}$ is the thermal conductivities of the adjacent elements at $i-1$ step.

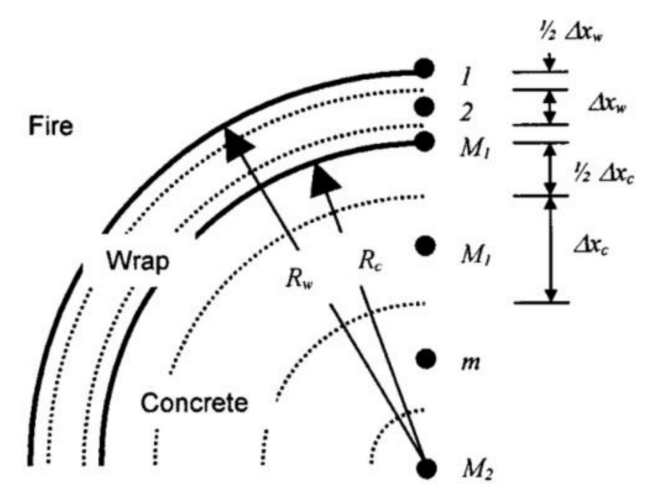

Figure 10. Discretization of cross section for heat transfer analysis (adapted from Reference [91]).

At any time, the above equation can be used to calculate the current temperature at any location in the column according to the thermal properties and temperature of the adjacent elements of the previous time step. Therefore, a complete temperature history of the entire column can be obtained. The axial load was approximated when the temperature distribution of the cross section after fire exposure was known.

However, since the mechanical properties of FRP do not perform very well at an elevated temperature, the improvement by adding insulation is a good choice for its performance. The specific 
model proposed by Spolestra and Monti [93] was chosen to calculate the confining pressure induced by a FRP sheet. The equation of lateral strain $\varepsilon_{\text {lat }}$ is as follows:

$$
\varepsilon_{\text {lat }}=\frac{E_{c} \varepsilon_{a}-f_{c}}{2 \beta f_{c}}
$$

where $\beta=\frac{5700}{\sqrt{f_{c o}^{\prime}}}-500$

The overall lateral strain of the column $\varepsilon_{\text {lot }}$ can be obtained from Equation (7):

$$
\varepsilon_{\text {lot }}=\frac{\sum_{m=M_{1}}^{M_{2}}\left(\varepsilon_{\text {lat }}+\varepsilon_{T}\right)_{m}}{M_{2}-M_{1}}
$$

Then Manfredi and Realfonzo [94] got the confining pressure $f_{\text {lat }}$ induced by the FRP sheet by developing this formulation:

$$
f_{\text {lat }}=0.685 \cdot \frac{2 t_{w} E_{w} \varepsilon_{l o t}}{d_{w}}
$$

where

$t_{w}$ is the FRP sheet thickness;

$E_{w}$ is the modules of the FRP at the current average wrap temperature;

$d_{w}$ is the average diameter of the wrap.

Compared with the available test results, although the numerical model is considered to be conservative, the overall trend of the fire behavior of FRP wrapped and insulated RC columns can be relatively accurately predicted.

\section{Conclusions}

This paper presented a review of the repair methods for fire-damaged compressed reinforced concrete elements.

The section enlargement method, steel wrapping strengthening and externally bonded reinforcement (EBR) technique were adopted to repair the fire-damaged RC columns. The section enlargement method can effectively improve the structural bearing capacity, stiffness, and stability, especially for compressed members. Although the construction is simple, the clearance of the building is reduced, which affects the subsequent use.

The fire-damaged columns and bridge piers were usually repaired by steel wrapping in China. The steel jacketing can prevent the concrete spalling besides increasing the ultimate load capacity. Moreover, the original compressive stress in the concrete columns can be relieved and the designed strength of fire-damaged columns can be restored by use of the post-compressed steel plate repair method. However, the connection between concrete and steel plates was a critical issue; meanwhile, it is necessary to improve the anti-corrosion ability of the repaired columns.

The mechanics of the FRP jacketing system for fire-damaged RC columns have been extensively researched. Compared with steel jacketing and concrete enlargements, the advantages of NSM FRP jacketing are ease of handling, light weight, anti-corrosion and high strength/stiffness-to-weight ratio. In the meantime, compared with EBR jacketing, the advantages of NSM FRP jacketing are more obvious, such as a better anchoring of the FRP and more ductile performance. The concrete was subjected to three-directional compression due to the confinement effects provided by FRP jacketing, hence the ultimate strength of columns increased significantly. However, FRP jacketing is a permanent repair; the fire resistance of the repaired column should be provided because the FRP is sensitive to high temperatures. 
Author Contributions: J.Z. reviewed references; and L.W. conceived the idea and wrote the paper.

Funding: This research was funded by the National key research and development program of China (Grant No. 2017YFC0703001) and National Natural Science Foundation of China (Grant No. 51678297).

Conflicts of Interest: The authors declare no conflict of interest.

\section{References}

1. Xiao, Y.; Tomii, M.; Sakino, K. Experimental study on design method to prevent shear failure of reinforced concrete short circular columns by confining in steel tube. Trans. Jpn. Concr. Inst. 1986, 8, 535-542.

2. Priestly, M.J.N.; Seible, F.; Xiao, Y.; Verma, R. Steel jacket retrofitting of reinforced concrete bridge columns for enhanced shear strength-part 1: Theoretical considerations and test design. Aci Struct. J. 1994, 91, $394-405$.

3. Priestley, M.J.N.; Seible, F.; Xiao, Y. Steel jacket retrofitting of reinforced concrete bridge columns for enhanced shear strength-Part 2: Test results and comparison with theory. Aci Struct. J. 1994, 91, 537-551.

4. Xiao, Y.; Wu, H. Retrofit of reinforced concrete columns using partially stiffened steel jackets. J. Struct. Eng. 2003, 129, 725-732. [CrossRef]

5. Cirtek, L. RC columns strengthened with bandage-experimental programme and design recommendations. Constr. Build. Mater. 2001, 15, 341-349. [CrossRef]

6. Cirtek, L. Mathematical model of RC banded column behaviour. Constr. Build. Mater. 2001, 15, 351-359. [CrossRef]

7. Adam, J.M.; Ivorra, S.; Giménez, E.; Moragues, J.J.; Miguel, P.; Miragall, C.; Calderon, P.A. Behaviour of axially loaded RC columns strengthened by steel angles and strips. Steel Compos. Struct. 2007, 7, 405. [CrossRef]

8. Adam, J.M.; Giménez, E.; Calderón, P.A.; Pallarés, F.J.; Ivorra, S. Experimental study of beam-column joints in axially loaded RC columns strengthened by steel angles and strips. Steel Compos. Struct. 2008, 8, 329-342. [CrossRef]

9. Adam, J.M.; Ivorra, S.; Pallarés, F.J.; Jimenez, E.; Calderón, P.A. Column-joint assembly in RC columns strengthened by steel caging. Available online: https:/ /www.icevirtuallibrary.com/doi/10.1680/stbu.2008. 161.6.337 (accessed on 1 February 2019).

10. Adam, J.M.; Ivorra, S.; Pallarés, F.J.; Giménez, E.; Calderón, P.A. Axially loaded RC columns strengthened by steel caging. Finite element modelling. Constr. Build. Mater. 2009, 23, 2265-2276. [CrossRef]

11. Adam, J.M.; Ivorra, S.; Pallarés, F.J.; Giménez, E.; Calderón, P.A. Axially loaded RC columns strengthened by steel cages. Proc. ICE-Struct. Build. 2009, 162, 199-208. [CrossRef]

12. Giménez, E.; Adam, J.M.; Ivorra, S.; Calderón, P.A. Influence of strips configuration on the behaviour of axially loaded RC columns strengthened by steel angles and strips. Mater. Des. 2009, 30, 4103-4111. [CrossRef]

13. Giménez, E.; Adam, J.M.; Ivorra, S.; Moragues, J.J.; Calderón, P.A. Full-scale testing of axially loaded RC columns strengthened by steel angles and strips. Adv. Struct. Eng. 2009, 12, 169-181. [CrossRef]

14. Garzón-Roca, J.; Adam, J.M.; Calderón, P.A. Behaviour of RC columns strengthened by steel caging under combined bending and axial loads. Constr. Build. Mater. 2011, 25, 2402-2412. [CrossRef]

15. Garzón-Roca, J.; Ruiz-Pinilla, J.; Adam, J.M.; Calderón, P.A. An experimental study on steel-caged RC columns subjected to axial force and bending moment. Eng. Struct. 2011, 33, 580-590. [CrossRef]

16. Yang, K.H.; Ashour, A.F. Tests of reinforced concrete short columns laterally strengthened with wire rope units and steel elements. Mag. Concr. Res. 2007, 59, 547-557. [CrossRef]

17. Yang, K.H.; Ashour, A.F.; Lee, E.T. Axial behavior of reinforced concrete short columns strengthened with wire rope and T-shaped steel plate units. Mag. Concr. Res. 2009, 61, 143-154. [CrossRef]

18. Li, J.; Gong, J.; Wang, L. Seismic behavior of corrosion-damaged reinforced concrete columns strengthened using combined carbon fiber-reinforced polymer and steel jacket. Constr. Build. Mater. 2009, 23, 2653-2663. [CrossRef]

19. Montuori, R.; Piluso, V. Reinforced concrete columns strengthened with angles and battens subjected to eccentric load. Eng. Struct. 2009, 31, 539-550. [CrossRef]

20. Smith, S.T.; Teng, J.G. FRP-strengthened RC beams. I: Review of debonding strength models. Eng. Struct. 2002, 24, 385-395. [CrossRef] 
21. Tao, Z.; Yu, Q. New Types of Composite Columns Experiments, Theory and Methodology; China Science Press: Beijing, China, 2006; ISBN 7-03-016824-0.

22. Zhao, X.L.; Zhang, L. State-of-the-art review on FRP strengthened steel structures. Eng. Struct. 2007, 29, 1808-1823. [CrossRef]

23. Teng, J.G.; Chen, J.F.; Smith, S.T.; Lam, L. Behaviour and strength of FRP-strengthened RC structures: A state-of-the-art review. Available online: https:/ / www.icevirtuallibrary.com/doi/10.1680/stbu.2003.156.1.51 (accessed on 1 February 2019).

24. Burke, P.J.; Bisby, L.A.; Green, M.F. Effects of elevated temperature on near surface mounted and externally bonded FRP strengthening systems for concrete. Cem. Concr. Comp. 2013, 35, 190-199. [CrossRef]

25. Palmieri, A.; Matthys, S.; Taerwe, L. Experimental investigation on fire endurance of insulated concrete beams strengthened with near surface mounted FRP bar reinforcement. Compos. Part B Eng. 2012, 43, 885-895. [CrossRef]

26. Palmieri, A.; Matthys, S.; Taerwe, L. Fire Endurance and Residual Strength of Insulated Concrete Beams Strengthened with Near-Surface Mounted Reinforcement. J. Compos. Constr. 2013, 17, 454-462. [CrossRef]

27. Thi, C.N.; Pansuk, W.; Torres, L. Flexural behavior of fire-damaged reinforced concrete slabs repaired with near-surface mounted (NSM) carbon fiber reinforced polymer (CFRP) rods. J. Adv. Concr. Technol. 2015, 13, 15-29. [CrossRef]

28. Kodur, V.K.R.; Baolin, Y. Evaluating the Fire Response of Concrete Beams Strengthened with Near-Surface-Mounted FRP Reinforcement. J. Compos. Constr. 2013, 17, 517-529. [CrossRef]

29. Rein, G.; Abecassis, E.C.; Carvel, R. (Eds.) The Dalmarnock Fire Tests: Experiments and Modeling; School of Engineering and Electronics, University of Edinburgh: Edinburgh, UK, 2007.

30. Al-Mahmoud, F.; Castel, A.; Francois, R.; Tourneur, C. RC beams strengthened with NSM CFRP rods and modeling of peeling-off failure. Compos. Struct. 2010, 92, 1920-1930. [CrossRef]

31. De Lorenzis, L.; Teng, J.G. Near-surface mounted FRP reinforcement: An emerging technique for strengthening structures. Compos Part B Eng. 2007, 38, 119-143. [CrossRef]

32. Chen, M.T.; Young, B. Material properties and structural behavior of cold-formed steel elliptical hollow section stub columns. Thin-Walled Struct. 2019, 134, 111-126. [CrossRef]

33. Li, L.Z.; Liu, X.; Yu, J.T.; Lu, Z.D.; Su, M.N.; Liao, J.H.; Xia, M. Experimental study on seismic performance of post-fire reinforced concrete frames. Eng. Struct. 2019, 179, 161-173. [CrossRef]

34. Lai, M.H.; Hanzic, L.; Ho, J.C.M. Fillers to improve passing ability of concrete. Struct. Concrete 2018. [CrossRef]

35. Lai, M.H.; Ho, J.C.M. A theoretical axial stress-strain model for circular concrete-filled-steel-tube columns. Eng. Struct. 2016, 125, 124-43. [CrossRef]

36. Tan, K.H.; Yao, Y. Fire Resistance of Four-Face Heated Reinforced Concrete Columns. J. Struct. Eng. Asce. 2003, 129, 1220-1229. [CrossRef]

37. Tan, K.H.; Yao, Y. Fire Resistance of Reinforced Concrete Columns Subjected to 1-, 2-, and 3-Face Heating. J. Struct. Eng. Asce. 2004, 130, 1820-1828. [CrossRef]

38. Jau, W.C.; Huang, K.L. A study of reinforced concrete corner columns after fire. Cement Concrete Comp. 2008, 30, 622-638. [CrossRef]

39. Lie, T.T. Fire Resistance of Circular Steel Columns Filled with Bar-reinforced Concrete. J. Struct. Eng. Asce. 1994; 120, 1489-1509.

40. Lie, T.T.; Irwin, R.J. Fire Resistance of Rectangular Steel Columns Filled with Bar-reinforced Concrete. J. Struct. Eng. Asce. 1995, 121, 797-805. [CrossRef]

41. Lie, T.T.; Kodur, V.K.R. Fire Resistance of Steel Columns Filled with Bar-reinforced Concrete. J. Struct. Eng. Asce. 1996, 122, 30-36. [CrossRef]

42. Wu, B.; Hong, Z.; Tang, G.H.; Wang, C. Fire Resistance of Reinforced Concrete Columns with Square Cross Section. Fire Saf. J. 2009, 44, 869-880. [CrossRef]

43. Rilem, T.C. RILEM Technical Recommendations for the Testing and Use of Constructions Materials, 1st. ed.; CRC Press: Boca Raton, FL, USA, 1994.

44. Rehm, G.; Eligehausen, R. Bond of ribbed bars under high cycle repeated loads. J. Am. Concr. Inst. 1979, 76, 297-309.

45. Vos, E.; Reinhardt, H. Influence of loading rate on bond behaviour of reinforcing steel and prestressing strands. Mater Constr. 1982, 15, 3-10. [CrossRef] 
46. Bosnjak, J.; Sharma, A.; Ottl, C. Modified beam-end test setup to study the bond behavior of reinforcement in concrete after fire. Mart Mater Struct. 2018, 51, 13. [CrossRef]

47. Bett, B.J.; Klingner, R.E.; Jirsa, J.O. Lateral Load Response of Strengthened and Repaired Reinforced Concrete Columns. Aci. Struct. J. 1988, 499-508.

48. Deng, X.D.; Wang, L. Application of section enlargement method in fire-damaged bridge reinforcement. J. Mt. 2016, 13, 66-71. (In Chinese).

49. Liu, L.X.; Shi, X.D.; Guo, Z.H. Experimental Investigation of Strengthened Reinforced Concrete Columns After Exposure to High Temperature. Eng. Mech. 2003, 5, 18-23. (In Chinese)

50. Gholampour, A.; Hassanli, R.; Mills, J.E.; Vincent, T.; Kunieda, M. Experimental investigation of the performance of concrete columns strengthened with fiber reinforced concrete jacket. Constr. Build. Mater. 2019, 194, 51-61. [CrossRef]

51. Fu, W. Assessment and Reinforcement of Fire-damaged Concrete Structures Based on Fire Temperature and Material Properties. Master's Thesis, Nanchang University, Nanchang, China, 2015. (In Chinese)

52. Wang, L.; Su, R.K.L. Repair of Fire-Exposed Preloaded Rectangular Concrete Columns by Postcompressed Steel Plates. J. Struct. Eng. Asce. 2014, 140, 04013083. [CrossRef]

53. Wang, L.; Su, R.K.L. Theoretical and experimental study of plate-strengthened concrete columns under eccentric compression loading. J. Struct. Eng. 2012, 139, 350-359. [CrossRef]

54. Su, R.K.L.; Wang, L. Axial strengthening of preloaded rectangular concrete columns by precambered steel plates. Eng. Struct. 2012, 38, 42-52. [CrossRef]

55. Wang, L.; Su, R.K.L. Experimental investigation of preloaded RC columns strengthened with precambered steel plates under eccentric compression loading. Adv. Struct. Eng. 2012, 15, 1253-1264. [CrossRef]

56. Su, R.K.L.; Wang, L. Flexural and axial strengthening of preloaded concrete columns under large eccentric loads by flat and precambered steel plates. Struct. Infrastruct. Eng. 2015, 11, 1083-1101. [CrossRef]

57. Wang, L.; Su, R.K.L. Strengthening of preloaded RC columns by post compressed plates-a review. Struct. Eng. Mech. 2018, 65, 477-490.

58. Wang, L.; Su, R.K.L.; Cheng, B.; Li, L.Z.; Wan, L.; Shan, Z.W. Seismic behavior of preloaded rectangular RC columns strengthened with precambered steel plates under high axial load ratios. Eng. Struct. 2017, 152, 683-697. [CrossRef]

59. Sun, J.F. Comparative Experiments of the Behavior of Reinforced Concrete Members Exposed to Different Elevated Temperature Modes. Master's Thesis, Tsinghua University, Beijing, China, 2001. (In Chinese)

60. Wu, Q.; Yang, F.Y.; Sun, G.Q.; Liu, W.Q.; Wang, L. Analytical method for determination of temperatureinduced interfacial shear stress in foam-core composite sandwich materials. Plast. Rubber Compos. 2018, 47, 232-239. [CrossRef]

61. Wang, L.; Wu, Z.M.; Liu, W.Q.; Wan, L. Structural behavior of load-bearing sandwich wall panels with GFRP skins and a foam-web core. Sci. Eng. Compos. Mater. 2016, 25, 173-188. [CrossRef]

62. Zhang, L.F.; Liu, W.Q.; Sun, G.Q.; Wang, L.; Li, L.Z. Two-dimensional Modeling of Thermo-mechanical Responses of Rectangular GFRP Profiles Exposed to Fire. Adv. Mater. Sci. Eng. 2017, 2017. [CrossRef]

63. Xia, Y.W.; Li, X.P.; Peng, Y.; Lai, M.H.; Wang, L. Impact and Post-Impact Performance of Sandwich Wall Boards with GFRP Face Sheets and a Web-Foam Core: The Effects of Impact Location. Materials 2018, 11. [CrossRef] [PubMed]

64. Wang, X.K.; Ma, Y.L.; Liu, W.Q.; Liang, R.F.; Wang, L. Mode I interfacial fracture characterization of foam core sandwich materials at elevated temperatures. J. Reinf. Plast. Compos. 2018, 36, 1009-1018. [CrossRef]

65. Fang, Y.; Wang, K.; Hui, D.; Xu, F.J.; Liu, W.Q.; Yang, S.L.; Wang, L. Monitoring of seawater immersion degradation in glass fibre reinforced polymer composites using quantum dots. Compos. Part B 2017, 112, 93-102. [CrossRef]

66. Wang, L.; Fan, X.M.; Chen, H.; Liu, W.Q. Axial crush behavior and energy absorption capability of foam-filled GFRP tubes under elevated and high temperature. Compos. Struct. 2016, 149, 339-350. [CrossRef]

67. Mostofinejad, D.; Moshiri, N. Compressive strength of CFRP composites used for strengthening for RC columns: Comparative evaluation of EBR and grooving method. ASCE J. Compos. Constr. 2015, 19, 04014079. [CrossRef]

68. Maaddawy, T.; Sayed, M.; Magid, B.A. Effect of cross sectional shape and loading condition on performance of reinforced concrete members confined with carbon fiber reinforced polymers. Mater Des. 2013, 31, 2330-2341. [CrossRef] 
69. Hadi, M.N.S.; Zhao, H. Experimental study of high strength concrete columns confined with different types of mesh under eccentric and concentric loading. ASCE J. Mater. 2013, 23.

70. Herwig, A.; Motavalli, M. Axial behavior of square Reinforced Concrete columns strengthened with lightweight concrete elements and unbonded GFRP wrapping. Asce, J. Compos. Constr. 2016, 16, 747-752. [CrossRef]

71. Song, X.; Gu, X.; Li, Y.; Chen, T.; Zhang, W. Mechanical behavior of FRP strengthened concrete columns subjected to concentric and eccentric compression. ASCE J. Compos. Constr. 2013, 17, 336-346. [CrossRef]

72. Hamdy, M.; Afifi, M.M.Z.; Benmokrane, B. Performance evaluation of concrete columns reinforced longitudinally with FRP bars and confined with FRP hoops and spirals under axial load. ASCE J. Bridge Eng. 2014, 19, 04014020.

73. Lam, L.; Teng, J.G. Design oriented stress strain model for FRP confined concrete. Constr. Build Mater 2003, 17, 471-489. [CrossRef]

74. Lam, L.; Teng, J.G. A new stress strain Model for FRP confined concrete. Proc. Frp. Compos. 2001, 1, $283-292$.

75. Rocca, S.; Galati, N.; Nanni, A. Review of design guidelines for FRP confinement of Reinforced Concrete columns of noncircular cross sections. ASCE J. Compos. Constr. 2008, 12, 80-92. [CrossRef]

76. Chellapandian, M.; Prakash, S.S.; Sharma, A. Strength and ductility of innovative hybrid NSM reinforced and FRP confined short RC columns under axial compression. Compos. Struct. 2017, 176, 205-216. [CrossRef]

77. Tao, Z.; Han, L.H.; Wang, L.L. Compressive and flexural behavior of CFRP-repaired concrete-filled steel tubes after exposure to fire. J. Constr. Steel Res. 2007, 63, 1116-1126. [CrossRef]

78. Tao, Z.; Wang, Z.B.; Han, L.H.; Uy, B. Fire performance of concrete-filled steel tubular columns strengthened by FRP. Steel Compos. Struct. 2011, 11, 307-324. [CrossRef]

79. Janwaena, W.; Barrosa, J.A.; Costa, I.G. A new strengthening technique for increasing the load carrying capacity of rectangular reinforced concrete columns subjected to axial compressive loading. Compos. Part $B$ 2019, 158, 67-81. [CrossRef]

80. Haji, M.; Naderpour, H.; Kheyroddin, A. Experimental study on influence of proposed FRP-strengthening techniques on RC circular short columns considering different types of damage index. Compos. Struct. 2019, 209, 112-128. [CrossRef]

81. Yaqub, M.; Bailey, C.G. Repair of fire damaged circular reinforced concrete columns with FRP composites. Constr. Build. Mater. 2011, 25, 359-370. [CrossRef]

82. Roudsaria, S.S.; Hamoushb, S.A.; Soleimanic, S.M.; Madandoust, R. Evaluation of large-size reinforced concrete columns strengthened for axial load using fiber reinforced polymers. Eng. Struct. 2019, 178, 680-693. [CrossRef]

83. Bisby, L.A.; Kodur, V.K.R.; Green, M.F. Fire endurance of fiber-reinforced polymer-confined concrete columns. Aci. Struct. J. 2005, 102, 883-891.

84. Chowdhury, E.U.; Bisby, L.A.; Green, M.F.; Kodur, V.K.R. Investigation of insulated FRP-wrapped reinforced concrete columns in fire. Fire Saf. J. 2007, 42, 452-460. [CrossRef]

85. Kodur, V.K.R.; Bisby, L.A.; Green, M.F. Experimental evaluation of the fire behavior of insulated fibrereinforced-polymer-strengthened reinforced concrete columns. Fire Saf. J. 2006, 41, 547-557. [CrossRef]

86. Benichou, N.; Cree, D.; Chowdhury, E.U.; Green, M. Fire testing of FRP strengthened reinforced concrete columns. In Proceedings of the 4th International Conference on Durability and Sustainability of FRP Composites for Construction and Rehabilitation, Québec, QC, Canada, 20-22 July 2011.

87. Wang, L. Application of the section-enlargement method in reinforcing the fire-damaged bridge. Master's Thesis, Southeast University, Nanjing, China, 2015. (In Chinese)

88. Wang, W.D.; Guo, Z.F.; Zhang, P.P. Numerical simulation on strengthening behavior of reinforced concrete columns after fire with wrapped steel tube. J. Nat. Disaster. 2012, 21, 204-210. (In Chinese)

89. Han, L.H.; Yang, Y.F.; Xu, L. An experimental study and calculation on the fire resistance of concrete-filled SHS and RHS columns. J. Constr Steel Res. 2003, 59, 427-452. [CrossRef]

90. Bisby, L.A.; Green, M.F.; Kodur, V.K.R. Modeling the behavior of fiber reinforced polymer-confined concrete columns exposed to fire. J. Compos. Constr. 2005, 9, 15-24. [CrossRef]

91. Bisby, L.A.; Kodur, V.K.R.; Green, M.F. Numerical parametric studies on the fire endurance of fibre-reinforcedpolymer-confined concrete columns. Can. J. Civ. Eng. 2004, 31, 1090-1100. [CrossRef]

92. Kodur, V.K.R.; Lie, T.T. Evaluation of the fire resistance of rectangular steel columns filled with fibrereinforced concrete. Can. J. Civ. Eng. 1997, 24, 339-349. [CrossRef] 
93. Spoelstra, M.R.; Monti, G. FRP-confined concrete model. J. Compos. Constr. 1999, 3, 143-150. [CrossRef]

94. Manfredi, G.; Realfonzo, R. Models for concrete confined by fiber composites. Available online: https://www. researchgate.net/publication/262259777_Models_of_concrete_confined_by_fiber_composites (accessed on 1 February 2019). 